\section{Practical ways of alleviating auditory hallucinations}

\author{
Hazel E Nelson, Sian Thrasher, \\ Thomas R E Barnes
}

Academic Unit, Charing Cross and Westminster Medical School, Horton Hospital, Epsom, Surrey KT19 8PZ

Hazel E Nelson, PHD, principal clinical psychologist Sian Thrasher, BSC, graduate psychologist

Thomas R E Barnes, MD, senior lecturer

Correspondence to:

Dr Nelson.

BMf 1991;302:327 patients with chronic schizophrenia.

\section{Patients, methods, and results}

In selected patients auditory hallucinations have been found to respond to several non-pharmacological interventions, ${ }^{1}$ among the simplest of which are the use of an ear plug, ${ }^{2}$ the use of a personal cassette recorder, ${ }^{3}$ and various vocalisation tasks. ${ }^{4}$ We evaluated the acceptability and efficacy of these interventions in

We studied 20 consecutive patients with chronic schizophrenia (17 inpatients and three outpatients) who had been referred for non-pharmacological treatment of persistent auditory hallucinations. All were receiving maintenance treatment with antipsychotic drugs.

We tested three treatments: $(a)$ ear plugs - the patient inserted a wax ear plug into one ear; $(b)$ subvocal counting-the patient repeated a simple number sequence (for example, 123,123, .. ) under his or her breath; and $(c)$ a personal cassette playerthe patient listened to music through the headphones of a portable cassette player. (Patients could use the cassette player for pleasure as well as for treatment, and it was made clear that keeping the player was not contingent on its use or success as a treatment.) The treatments were introduced separately in the order ear plug, subvocal counting, and cassette player. The patients were advised to use each treatment during the week after its introduction whenever the voices became troublesome. The effects of the treatment were evaluated from the patient's subjective report. At regular follow up appointments (at least monthly) we noted whether the patient continued to use any of the treatments to alleviate the hallucinations.

The table shows the immediate effects of the treatments and their long term use. All three patients who refused any treatment described their hallucinations as unpleasant in content but of great significance. One patient stopped treatment with the cassette player when his voices threatened him for trying to stop them. Only one patient reported that none of the treatments was effective. In most cases the beneficial effects of treatment were limited to the period of use and shortly thereafter. Five patients, however, reported a more general effect of treatment on the frequency or intrusiveness of their hallucinations; two of these said that the hallucinations disappeared completely for several months after they used the ear plug.

Immediate effectiveness and long term use of treatments in 20 cases

\begin{tabular}{lcccc}
\hline & $\begin{array}{c}\text { One or more } \\
\text { treatments }\end{array}$ & $\begin{array}{c}\text { Ear } \\
\text { plug }\end{array}$ & $\begin{array}{c}\text { Subvocal } \\
\text { counting }\end{array}$ & $\begin{array}{c}\text { Cassette } \\
\text { player }\end{array}$ \\
\hline Patients attempting treatment & 17 & 13 & 8 & 15 \\
$\begin{array}{l}\text { Patients reporting some } \\
\text { immediate beneficial effects }\end{array}$ & 16 & 8 & 5 & 14 \\
$\begin{array}{c}\text { Patients using treatment } \\
\text { long term }\end{array}$ & 11 & 4 & 2 & 7 \\
\hline
\end{tabular}

\section{Comment}

The cassette player was the most popular and effective treatment, but headphones may restrict social interaction and are not always socially appropriate. Although wearing an ear plug was preferred by fewer patients, it has the advantage of being compatible with any other activity. Subvocal counting was the least popular treatment; an easier subvocal task for future use may be singing quietly to oneself. The cassette player and ear plugs probably involve two processes important for relieving auditory hallucinations'namely, shifting attention and reducing anxiety-and subvocal counting may work by disrupting the subvocal activity that is concomitant with the voices. Whatever the theoretical arguments, auditory hallucinations can be a persistent and distressing symptom so these simple, cheap, and practical ways of alleviating them may be useful adjuncts to antipsychotic drugs. That they are non-invasive and carry no risk of adverse reactions or side effects are additional attractions.

We and the patients are indebted to Aiwa (UK) Ltd, Ferguson Ltd, Sony (UK) Ltd, and Panasonic UK for their generosity in donating the personal cassette players for research and treatment. A longer version of this paper is available on request.

1 Slade PD, Bentall RP. Sensory deception: a scientific analysis of hallucination. London: Croom Helm, 1988

2 Done DJ, Frith CD, Owens DC. Reducing persistent auditory hallucination by wearing an ear-plug. $\mathrm{Br} f \mathrm{Clin} P$ sychol 1986;25:151-2.

Collins MN, Cull CA, Sireling L. Pilot study of treatment of persistent auditory hallucinations by modified auditory input. BMF 1989;229:431-2.

4 Margo A, Hemsley DR, Slade PD. The effects of varying auditory input on schizophrenic hallucinations. Br f Psych 1981;139:122-7.

(Accepted 4 December 1990)

\section{Department of}

Microbiology, Walton

Hospital, Liverpool

L9 1AE

Miles Denton, BM, senior

house officer

Marina S Morgan, MB,

registrar

Ruth R White, MB, senior

registrar

Correspondence to:

Dr M Denton, Department

of Microbiology, Old

Medical School, Leeds

LS2 9JT.

BMf 1991;302:327-8

\section{Quality of prescribing of intravenous antibiotics in a district general hospital}

\section{Miles Denton, Marina S Morgan, Ruth R White}

The number of patients being admitted to hospitals is increasing and treatment is becoming more intensive. In one study the use of intravenous cannulas increased by $150 \%$ from 1981 to 1989 yet junior medical staffing levels increased by only $8 \%$ over the same period. Thus junior medical staff are spending more of their time performing procedures relating to intravenous treatment, and it has been suggested that hours and conditions could be improved by redistributing some of these tasks to non-medical staff, as is practised in many European countries. ${ }^{2}$ We carried out a survey to assess the participation of nursing staff in giving intravenous antibiotics and the effect this had on quality of prescribing.

\section{Patients, methods, and results}

The survey was carried out over one complete week during winter 1989-90 in a district general hospital with 570 beds distributed among 10 disciplines, including a supraregional referral centre for neurosciences and two intensive therapy units. Data were collected by three junior microbiology staff, in collaboration with pharmacy staff, on all inpatients who had been prescribed intravenous antibiotics. The staff recorded the drug prescribed, its dose and frequency, the times it was due to be given (as stated on the prescription chart), the presence or absence of the signature of the person who gave each individual dose, and the discipline of the person who gave the drug. We then calculated the average times between doses for 